\title{
Effects of Handep Cooperative Learning Based on Indigenous Knowledge on Mathematical Problem Solving Skill
}

\section{Demitra}

Dr., Study Program of Mathematics Education, University of Palangka Raya, Indonesia, demitra@fkip.upr.ac.id

\section{Sarjoko}

Study Program of Mathematics Education, University of Palangka Raya, Indonesia, sarjoko@math.upr.ac.id

\begin{abstract}
Indigenous people of Dayak tribe in Kalimantan, Indonesia have traditionally relied on a system of mutual cooperation called handep. The cultural context has an influence on students mathematics learning. The handep system might be suitable for modern learning situations to develop mathematical problem-solving skill. The objective of the study was to investigate the effect of handep cooperative learning model compared to problem-based learning model on mathematical problem-solving skill of rational exponent material. The research was conducted through pretest-posttest non-equivalent control group design. The sample of 66 students was selected from the population of 304 students through cluster random sampling. The mathematical problem-solving skill assessed with essay test of the open-ended question had reliability coefficient of $r_{r_{x x^{\prime}}=} 0,71$. The students' answers scorings were obtained with the rubric of mathematical problem-solving skill. Data analysis is conducted through ANACOVA. The result presents that the mathematical problem-solving skill of students who learned through handep cooperative learning model is better than problem-based learning. Handep cooperative learning model is suitable to enhance the mathematical problem solving skill of students in Kalimantan-Indonesia cultural context. The teacher should construct the instructional material use metacognition questioning strategy and also be familiar to their students' prior knowledge of mathematics.
\end{abstract}

Keywords: handep cooperative learning, indigenous knowledge, metacognition questioning, problem-based learning, problem-solving skill

\section{INTRODUCTION}

Problem-solving skill has a central position in mathematics education. The skills to solve mathematical problems are a higher order thinking skill. According to Polya

Citation: Demitra, \& Sarjoko (2018). Effects of Handep Cooperative Learning Based on Indigenous Knowledge on Mathematical Problem Solving Skill. International Journal of Instruction, 11(2), 103114. https://doi.org/10.12973/iji.2018.1128a 
(1973) that there are four steps of mathematical problem solving as follow, understand the problem, devise a plan, carry out the plan, and look back (Yuan, 2013). Mathematical problem solving is a process which helps the students learn the concept and skill (Tarzimah et al., 2010).

However, teaching problem-solving in mathematical problems at school is not easy. Sarjoko (2003) has implemented the model of IMPROVE (Introduction new concept, Metacognition questioning strategy, Practicing, Reviewing and reducing, Obtaining mastery, Verification, and Enrichment) in cooperation setting and found that the tenthgrade students of the senior high school of SMAN-2 Palangka Raya of Central Kalimantan, Indonesia. IMPROVE model can develop rational exponent understanding of students' rational exponent concept partially. Nevertheless, students cannot make a relationship between prior knowledge in solving the rational exponent problem. The implementation of the model has not arrived at a rational learning of problem-solving yet and also cooperation setting has not stepped clearly.

On the other hand, in order to implement K-13 in Indonesia, problem-based learning has recommended teaching mathematical problem-solving. But students had difficulty when they learned mathematical problem solving using problem-based learning. According to classroom observation result of Demitra (2006), the students in Kalimantan have difficulty in cooperating. The steps of collaboration process of problem-based learning are unclear for students. The collaboration process has not been optimal, leading to less successful mathematical problem-solving process. Jaelani and Retnawati (2016) found that the teacher has difficulties in implementing problem based learning. Other countries such as Canada and Spain in Sharif and Gisbert (2015) showed the cultural impact on teacher to design the instruction influenced.

The problem of developing problem-solving skill related to rational exponent can be solved through developing a model of cooperative learning that considers the cultural background of the student. The importance of cultural background like indigenous knowledge has widely recognized in mathematics learning. The findings of some research show that cultural background of students influenced their thinking and supported the high achievement in mathematics learning (Cimen, 2014; Verner et al., 2013; Weldeana, 2014). Cultural background such as indigenous knowledge system of a tribe has a potential to serve as a basis to develop the learning strategies (Breidlid, 2009; Letsekha et al., 2013). Warren et al. (2004) also found that the indigenous teacher aides were afforded greater authority when it came to behavioral management, especially when dealing with the indigenous students, and resulting in each being given greater responsibility for student learning. D’Entremont (2015) and Prediger (2004) stated the importance of adopting the cultural background into mathematics teaching and learning strategies.

Indigenous knowledge of mutual cooperation tradition of Indonesian tribes can inspire the syntax of the cooperative learning model. The Dayak tribe in central KalimantanIndonesia has long been working together in a traditional mutual help and cooperation called handep. Some people of Dayak tribe in the villages in Kalimantan-Indonesia have big burdens such as for farming, harvesting, keeping moving their house to another safe 
place, conducting wedding party (Taylor, 2009; Yanarita, et al 2014). The handep mutual cooperation system works (Demitra, et al., 2012):

"for example, exists in the harvest pattern. If each of families of A, B, and C wants to harvest the rice plant in the village, they make an agreement for finishing their work by handep mutual cooperation since they have no sophisticated technology for harvest. In the beginning, families of $\mathrm{A}, \mathrm{B}$, and $\mathrm{C}$ meet together to discuss how to do their work, and then they make an agreement by taking turns or shifts to help each other. The family of A gets the first turn help by families B and $\mathrm{C}$ to harvest the rice plant. When the rice plant of family A has been harvest completely, family B gets the second turn to be assisted. Family B will do the harvest assisted by the family of A and C. When the rice plant harvest of family B has been finished completely, family $\mathrm{C}$ gets the third turn for help".

The handep system might be suitable for modern learning situations. This indigenous knowledge has been used in order to solve daily life problem from generation to generation. The handep cooperative learning model is designed by adopting the stages of handep mutual cooperation of the Dayak tribe combined with the stages of Polya (1973) mathematical problem solving (Yuan, 2013). This model is called handep cooperative learning model. This model has been validated through learning expert and tried out on small group students. The learning expert stated that the model is suitable as a model of teaching and learning. The result of tryout showed that the students get the good skill to solve the problem of the number theory (Demitra, et al. 2012). This model has been implemented for learning of rational and irrational numbers of senior high school students of SMAN-3 Palangka Raya, Indonesia. The students can achieve good mastery of competencies including distinguishing, defining, finding the characteristic of rational and irrational numbers (Demitra, 2014).

The first step of handep cooperative learning model is to understand the prior knowledge. Prior knowledge must be understood as a base of students grouping in heterogeneous. It can make collaboration and knowledge sharing knowledge optimally. Prior knowledge has been known to influence the student's problem-solving skill and understanding of the mathematical concepts. The study of Bringula, et al. (2016) show that depending on prior knowledge, students can understand more of the terms of equations and the following steps in solving equations. Hohensee (2016) said that the performance of the problem solver is to mobilize the relevant elements of his knowledge and connect them with the element of his problem.

The second step of handep is cooperative learning syntaxes, in which student learn the material and reflect the problem mediated through metacognition questioning strategy. This is the strategy used to help students to understand the material and identified what their problem in learning the material. In this part, what part of the material has been understood and what part of the material has still difficult for students is understood. The questions, what do I understand from the material? Which point of the material or the problem is difficult for me? Which part don't I understand about the problem? Mevarech and Fridkin (2006) and Özsoy and Ataman (2009) said that the metacognition questioning strategy is one of the strategies which can be used for 
developing metacognition within the framework of constructivist learning to encourage the students to ask questions themselves. Kramarski and Mevarech (2003) find that the instructional methods of cooperative learning combined with metacognition training can enhance the mathematical reasoning.

Handep cooperative learning model can become a solution for learning to get problemsolving skill in mathematics. The research is conducted to know the influence of handep cooperative learning model compared with problem-based learning on mathematical problem-solving skill. The research problem is that; "Is the problem-solving skill of students who learned using handep cooperative learning better than problem-based learning?" The aim of the research is to find out the effect of handep cooperative learning compared to problem-based learning, on the problem-solving skill of rational exponent of mathematics.

The benefit of the research is to find out whether the model of cooperative learning is more suitable for mediated students' learning on problem-solving skill in the context of Kalimantan, Indonesia. The cooperation steps for collaboration are easier to implement in the context of students in Indonesia.

\section{METHOD}

\section{Students}

The population is 304 tenth-grade students in nine classes of the senior high school of SMAN-2 Palangka Raya. A total of 66 students in two classes was selected randomly through cluster random sampling. One class was randomly chosen as a treatment group $(\mathrm{n}=33)$ which was taught by handep cooperative learning model. The other class as the control group $(\mathrm{n}=33)$ was taught by the problem-based learning model.

\section{Experimental Procedure}

This research was carried out with the quasi-experimental design of pretest-posttest nonequivalent control group design (Creswell, 2012). The experiment conducted by pretest, treatment, and posttest. Treatment included teaching the students by handep cooperative learning model in the treatment group, and by problem-based learning in the control group. The same instructional material and worksheet were used to facilitate learning in both groups.

Treatment is provided by designing a lesson plan, instructional material, and worksheet. The mathematical content is the rational exponent of mathematics for senior high school. Two lesson plans and worksheets that used for teaching handep cooperative learning and problem-based learning model. Worksheet included a description of content and open-ended problems mediated through metacognition questions. Syntaxes of handep cooperative learning model (Demitra, 2011) and problem-based learning (Hmelo-Silver, 2004; Budé, et al, 2009) are as present in Table 1. 
Table 1

Syntaxes of handep cooperative learning and problem-based learning.

\begin{tabular}{|c|c|}
\hline Handep cooperative learning model & m-based learning \\
\hline $\begin{array}{l}\text { 1. Understand prior knowledge. } \\
\text { To understand students' prior knowledge, and } \\
\text { use it as a base for constructed student's group as } \\
\text { heterogeneous. } \\
\text { 2. Teacher introduces the new material. } \\
\text { 3. Solve the problem individually. } \\
\text { Individually, students learn the material and } \\
\text { solve the mathematical problem in a worksheet, } \\
\text { through problem-solving steps and mediated by } \\
\text { metacognition questioning strategy. } \\
\text { 4. Grouping the students of } 3-4 \text { peoples. } \\
\text { 5. Share individual problem. } \\
\text { Each member shares his/her individual problem } \\
\text { to others in the team. } \\
\text { 6. Solve the difficult problem together. } \\
\text { To conduct an agreement about solving the } \\
\text { individual problem in sequence the team begins } \\
\text { to solve the individual problem together, and get } \\
\text { solution one by one in turns. } \\
\text { 7. The team presents the solution and } \\
\text { celebrates their success. }\end{array}$ & $\begin{array}{l}\text { 1. Grouping the students of } 3-4 \text { people. } \\
\text { 2. Meeting the problem in the worksheet, read } \\
\text { the problem and understand the problem. } \\
\text { 3. Defining the problem. } \\
\text { Problem is only defined by the known parameters and } \\
\text { stated in question form. } \\
\text { 4. Gathering the facts. } \\
\text { Students tap into their previous experiences and prior } \\
\text { knowledge when gathering facts. Organizing the } \\
\text { information using a "know, need to know, need to } \\
\text { do". } \\
\text { 5. Hypothesizing. } \\
\text { Student theorizes or hypothesizes about the problem. } \\
\text { 6. Researching. } \\
\text { Explore the source of data and collect data depend on } \\
\text { the question that investigated. } \\
\text { 7. Rephrase the problem. } \\
\text { Refine the original problem statement. } \\
\text { 8. Generate alternatives. } \\
\text { Generate ideas and code them as probable, possible, } \\
\text { or preferable. }\end{array}$ \\
\hline
\end{tabular}

\section{Instruments}

Mathematical problem-solving skill assessed through essay test and then students' answers were assessed through an analytic rubric. Charles, et al. (1987) and Jonassen (2014) said that the problem-solving skill can be assessed using test and analytical rubric. The reliability coefficient of three items of essay test was calculated using the $\alpha$ -

Cronbach of $r_{x x^{\prime}}=0.71$. Analytic rubric including three aspects as understanding the problem, planning a solution and getting the answer (Charles, et al., 1987) are as presented in Table 2.

Table 2

The analytic rubrics of mathematical problem-solving skill.

\begin{tabular}{lll}
\hline $\begin{array}{l}\text { Aspects of problem- } \\
\text { solving skills }\end{array}$ & Levels of skill & Scores \\
\hline $\begin{array}{l}\text { Understand the } \\
\text { problem }\end{array}$ & Complete understanding of the problem. & 2 \\
& $\begin{array}{l}\text { Part of the problem misunderstood or misinterpreted. } \\
\text { Complete misunderstanding of the problem. }\end{array}$ & 1 \\
\hline \multirow{2}{*}{ Planning a solution } & $\begin{array}{l}\text { The plan could have led to a correct solution if implemented correctly. } \\
\text { Partially correct plan based on part of the problem being interpreted } \\
\text { correctly. }\end{array}$ & 2 \\
\hline & No attempt, or totally inappropriate plan. & 0 \\
\hline \multirow{2}{*}{ Getting answers } & Correct answer. & 2 \\
& $\begin{array}{l}\text { Copying error; computational error; the partial answer for a problem with } \\
\text { multiple answers. }\end{array}$ & 1 \\
\hline
\end{tabular}




\section{Analysis}

The data analysis started with scoring the students' answers to essay test used the analytic rubric. Analysis of Covariance (ANACOVA) was carried out to analyze the data at a significant level of 0.05 . The fulfillment of the assumption analyses of normality used Kolmogorov-Smirnov test and that of homogeneity used the Levene test. The data were analyzed with the software of SPSS 17 version.

\section{FINDINGS}

The aim of data analysis was to answer the research question: "Is it true that the mathematical problem-solving skills of students taught through handep cooperative learning are higher than that problem-based learning? The answer to the questions is presented below.

Table 3 presents the mean score of the student who learned using handep cooperative learning model before treatment of mathematical problem-solving skill of 18.00, which increased to 37.42 following the treatment. While the mean score of students who learned using problem-based learning model before treatment was 22.88 , which increased to 36.00 following the treatment.

Table 3

Mean score of mathematics problem-solving skill.

\begin{tabular}{llllll}
\hline \multirow{2}{*}{ Group } & \multirow{2}{*}{$\mathrm{N}$} & Pretest & \multicolumn{3}{l}{ Posttest } \\
\cline { 3 - 6 } & & Mean & SD & Mean & SD \\
\hline Experiment & 33 & 18.00 & 14.34 & 37.42 & 26.29 \\
Control & 33 & 22.88 & 15.24 & 36.00 & 21.24 \\
Total & 66 & 20.44 & 14.89 & 36.71 & 23.73 \\
\hline
\end{tabular}

Note: SD = Standard Deviation

Figure 1 presented the increase of means of mathematical problem-solving skill. The mean score of pretest was 18.00 and posttest was 37.42. Therefore, there was an increase of 19.42 points for the mathematical problem-solving skill of the students that learned using handep cooperative learning model. While in control group, the mean score of the students who learned through problem-based learning model was 22.88 for pretest and 36.00 for posttest. Therefore, there was an increase of 13.12 points. The increase of mean of problem-solving skill of experiment group was higher than the control group.

The $\mathrm{F}$ value of Levene was 4.16 at $\mathrm{p}=0.46$, which showed that the score of mathematic problem-solving skill has been fulfilled by homogeneity of variance. Table 4 shows the result of the Kolmogorov-Smirnov value of mathematical problem-solving skill of each pretest and posttest of control and experiment group has been fulfilled the normality.

Table 4

The assumption of normality fulfillment.

\begin{tabular}{lll}
\hline Group of scores & Kolmogorov-Smirnov & $p$ \\
\hline Experiment & & \\
Pretest & 0.13 & 0.14 \\
Posttest & 0.14 & 0.10 \\
Control & & \\
Pretest & 0.12 & 0.15 \\
Posttest & 0.14 & 0.08 \\
\hline
\end{tabular}




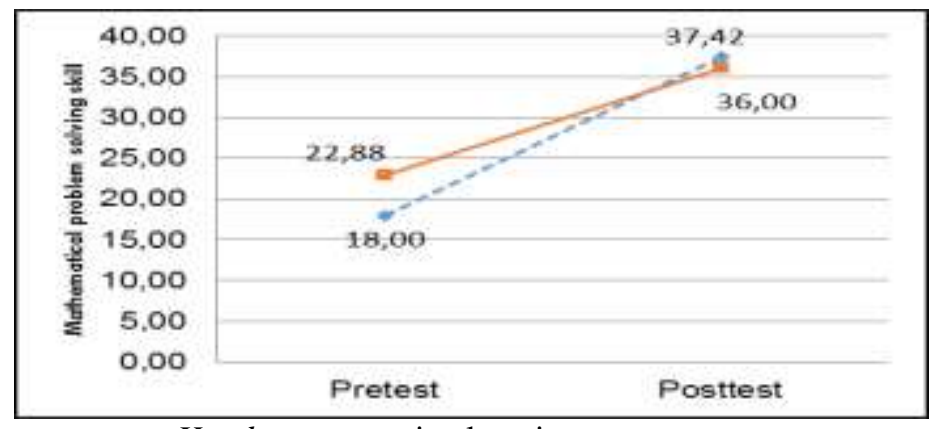

$---=$ Handep cooperative learning

Figure1

The increase of mathematical problem-solving skill.

The result of ANACOVA can be seen in Table 5. There is a difference in mathematics problem-solving skill of students who learned by handep cooperative learning model and those using problem-based learning model, which yielded of $F_{(1.63)}=3.94$ at a significant level of 0.05 . The result answered the research question before. The mathematical problem solving skill of students' who learn by handep cooperative learning model was higher than those using problem-based learning model, significantly.

Table5

The result of ANACOVA of mathematical problem-solving skill.

Tests of Between-Subjects Effects

\begin{tabular}{|c|c|c|c|c|c|}
\hline \multicolumn{6}{|c|}{ Dependent Variable: MPSS_POST-TEST ${ }^{*}$} \\
\hline \multicolumn{6}{|c|}{ Source $\quad$ Sum of quares } \\
\hline Corrected Model & $22005.55^{\mathrm{a}}$ & 2 & 11002.77 & 47.52 & 0.00 \\
\hline Intercept & 2748.26 & 1 & 2748.26 & 11.87 & 0.00 \\
\hline PRE-TEST & 21972.08 & 1 & 21972.08 & 94.90 & 0.00 \\
\hline Model of teaching $\left.{ }^{* *}\right)$ & 910.96 & 1 & 910.96 & 3.94 & 0.05 \\
\hline Error & 14585.98 & 63 & 231.52 & & \\
\hline Total & 125545.00 & 66 & & & \\
\hline Corrected Total & 36591.53 & 65 & & & \\
\hline a. R Squared $=0.60$ & sted R Squared = & & & & \\
\hline
\end{tabular}

Note : ${ }^{*}$ Mathematical problem solving skill

${ }^{* * *}$ Handep cooperative learning vs. problem-based learning

\section{DISCUSSION}

The finding of the research shows that students' mathematical problems solving skill taught by handep cooperative learning model is higher than the problem-based learning. It means that the handep cooperative learning model is more suitable for developing mathematical problem-solving ability if compared to the model of problem-based learning, for students in Central Kalimantan, Indonesia. The mutual cooperation through handep cooperative learning model influences the students' learning in the cultural 
context of Central Kalimantan, Indonesia. They become excited to cooperate in solving the problem. Students learn in teamwork through handep cooperation mechanism not to become awkward in asking questions and discussing in the team. They become more familiar with the handep cooperation mechanism. Zedda, et al (2017) said that students' working in a group of cooperative learning is related to student's satisfaction.

Handep cooperative learning as a model has been constructed a base on Dayak tribe indigenous knowledge in mutual cooperation, integrated to components of mathematical learning such as mathematical problem-solving steps of Polya, and metacognition questioning strategy. The integration of handep mutual cooperation with mathematical problem solving and metacognition questioning strategy makes this model effective for developing math problem-solving skills. The integration is also done by Park and Nuntrakune (2013) in mathematics learning for students in Thai, who have different cultures and difficulties to adopt cooperative learning model. Integration of Thai cultural and cooperative learning can improve mathematics achievement. The finding of the research proved the statement of Breidlid (2009), d'Entremont (2015), and also Letsekha et al., (2013) stating that the knowledge system of a tribe as indigenous knowledge forms the basis of the development of mathematics learning strategies.

The advantage of handep cooperative learning model compared to problem-based learning is that it facilitates the process of collaboration. First, the collaboration process of handep cooperative learning has been regulated with the steps in syntax. The steps in cooperative team facilitate the students to elaborate their cognitive by peer tutoring. When each student of the team helps others to solve the difficult individual mathematical problem, collaboration process has been done. Students explain the solution of math problem to others who have difficulties in solving the mathematical problem. The student who cannot understand the problem gets the solution after the other students guide him/her. Peer tutoring do at the moment of present the individual difficult and then make the solution of the individual problem together. The team in the heterogeneous ability of handep cooperative learning can enhance individual responsibility. Barron \& Hammond (2008) said that the heterogeneous ability of students in a team facilitate the learning process of mathematical problems and encourage individual responsibility. Similarly, Baiduri (2017) finds that peer tutoring improves students' activity in mathematics learning.

Second, math problem solving mediated through metacognitive questioning strategy in the setting of handep mutual cooperation encourages reasoning. The worksheet contains description of content and problems related to the rational exponent, inserted with metacognition question. For example, the rational exponent problem of $\left(2 a^{2}\right)^{\mathrm{I}}$ o metacognition questioning that mediated the students in understanding the problem, formulated i.e. "What problem is the problem is categorized?", "By which properties can the problem can be solved?" When reading the metacognition question, students attempt to think it by looking for reasons relevant to the problem. Students reopen the pages on a worksheet and find properties exponential number, and then select

the properties of $\left(a^{m m}\right)^{n}=a^{m n n}$, carefully. And they attempt to give a reason in their own mind, "why do I select that property?"Is that choice true?" 
Cooperative learning combined with metacognitive leaning outperform students' counterparts on both mathematical knowledge and mathematical reasoning (Mevarech \& Kramarski, 2003; Mevarech \& Fridkin, 2006).In order to develop the reasoning skill, handep cooperative learning model can use metacognition questioning strategy to mediate the reflective thinking and reasoning of students. The metacognition questioning strategy can help students' thinking to reflect their problem (Mevarech \& Fridkin, 2006), through asking the question to themselves (Özsoy \& Ataman, 2009). Metacognition can help students connect their prior knowledge to understand and solve the problem. When students work in the team to solve the mathematical problem through metacognition questioning strategy, this process helps them reflect their problem. Husamah (2015) said that the metacognitive knowledge includes knowledge about oneself as a learner and the factors that might impact performance, knowledge about strategies, and knowledge about when and why to use strategies. When the team is looking for the solution of the mathematical problem, all members have the opportunity to express the way of solving the problem and solve it together. The students' reasoning skill will improve until the team solves the problem. Husamah and Pantiwati (2014) said that the learning in cooperation context improves students thinking.

Third, handep cooperative learning model considers the prior knowledge of students. Prior knowledge is regarded as a base of grouping and the students of a team have the heterogeneous ability, especially in terms of prior knowledge. The team with heterogeneous ability supports the solving individual problem together. Prior knowledge is the important factor of learning the new mathematical concept. Hohensee (2016) said that the prior knowledge explicitly becomes clear when students make connections between prior knowledge and new learning, when they apply their prior knowledge to new contexts, and when they develop their prior knowledge as a result of applying that knowledge to new contexts.

\section{CONCLUSION AND IMPLICATION}

The finding of the research showed that handep cooperative learning model is more effective for learning mathematical problem solving compared to that of the model of problem-based learning. The model constructs integrated components of handep mutual cooperation steps, mathematical problem-solving step, and metacognition questioning strategy. Handep cooperative learning is more suitable for learning mathematical problem solving of students in Kalimantan, Indonesia.

Handep cooperative learning model is potential to be implemented in mathematics learning. However, the teacher should use metacognition questioning strategy. Metacognition questions strategy can be included in a worksheet or material description or can be delivered during collaborative team discussions. The teacher should know prior knowledge in the mathematics of students.

\section{REFERENCES}

Baiduri. (2017). Elementary school students' spoken activities and their respon in Math learning by peer-tutoring. International Journal of Instruction, 10/2, 145-160. Retrieved 2 October, 2017 from https://doi.org/10.12973/iji.2017.10210a. 
Barron, B., \& Hammond, L. D. (2008). Teaching for meaningful learning: A review on inquiry-based and cooperative learning. Edutopia. Retrieved 6 January, 2015 from http://www.edutopia.org/pdfs/edutopia-teaching-for-meaningful-learning.pdf.

Budé, I., Imbos, T., Wiel, M. W. J. V. D., Broers, N. J., \& Berger, M. P. F. (2009). The effect of directive tutor guidance in problem based learning of statistics on student's perceptions and achievement. Higher Education, 57/1, 23-36. Retrieved 17 October, 2017 from https://link.springer.com/article/10.1007/s10734-008-9130-8.

Breidlid, A. (2009). Culture, indigenous knowledge systems, and sustainable development: A critical view of education in an African context. International Journal of Educational Development,29/2, 140-148. Retrieved 17 October, 2017 from https://doi.org/10.1016/j.ijedudev.2008.09.009.

Bringula, R. P.; Basa, R. S., Cruz, C. D., \& Rodrigo, M. M. T. (2016). Effects of prior knowledge in mathematics on learner-interface interactions in a learning-by-teaching intelligent tutoring system. Journal of Educational Computing Research, 54/4, 462-482. $\begin{array}{lllll}\text { Retrieved } & 17 & \text { October, } & 2017 & \text { from }\end{array}$ http://journals.sagepub.com/doi/pdf/10.1177/0735633115622213.

Charles, R., Lester, F., \& O’Daffer, P. (1987). How to evaluate progress in problem-solving. Reston, VA.: National Council of Teacher of Mathematics.

Cimen, O. A. (2014). Discussing ethnomathematics: Is mathematics culturally dependent? In S. Beşoluk (Ed.), Proceeding of ERPA International Congress on Education, 2014. Istanbul, Turkey (pp. 523-528). Sakarya, Turkey: Faculty of Education, Sakarya University.

Creswell, J. W. (2012). Educational research: planning, conducting, and evaluating quantitative and qualitative research. Boston, MA: Pearson.

Demitra. (2006). Pengaruh model pembelajaran dan tipe masalah terhadap kemampuan pemecahan masalah matematika. [Effect of learning model and the type of problem to the mathematical problem-solving abilities]. Jurnal Ilmu Pendidikan, 13/2, 129-138. Retrieved 16 October, 2017 from http://dx.doi.org/10.17977/jip.v13i2.56.

Demitra, Sarjoko, \& Uda, S. K. (2012). Pengembangan model pembelajaran kooperatif handep untuk pembelajaran matematika [The development of handep cooperative learning model for mathematics learning]. Jurnal Pendidikan dan Pembelajaran, 19/1, 15-27. Retrieved 16 October, 2017 from http://journal.um.ac.id/index.php/pendidikan-danpembelajaran/article/view/3119/545.

Demitra \& Sarjoko. (2014). Penerapan model pembelajaran kooperatif handep pada materi pangkat rasional di SMAN-3 Palangka Raya. [The implementation of handep cooperative learning model on rational exponent in SMAN-3 Palangka Raya]. Jurnal Pendidikan dan Pembelajaran, 21/1, 48-60. Retrieved 2 May, 2016 from http://journal.um.ac.id/index.php/pendidikan-dan-pembelajaran/article/view/4521/991.

D’Entremont, Y. (2015). Linking mathematics, culture and community. In İşman, A. (Ed.) International Conference on New Horizons in Education, INTE 2014. Paris, France (pp. 2818-2824). Sakarya, Turkey: Sakarya University. Retrieved 5 November, 2016 from http://www.sciencedirect.com/science/article/pii/S1877042815010320.

Hohensee, C. (2016). Teachers' awareness of the relationship between prior knowledge and new learning. Journal for Research in Mathematics Education, 47/1, 17-27. Retrieved 16 October, 2017 from http://www.sciencedirect.com/science/article/pii/S1877042815010320. 
Hmelo-Silver, C. E. (2004). Problem-based learning: What and how do students learn? Educational Psychology Review, 16/3, 235-266.

Husamah \& Pantiwati, Y. (2014). Cooperative learning STAD-PjBL: motivation, thinking skills, and learning outcomes in Biology students. International Journal of Education Learning \& Development (IJELD), 2/2, 77-94. Retrieved 28 October, 2017 from http://www.ea-journals.org/.

Husamah. (2015). Blended project-based learning: Metacognitive awareness of biology education new students. Journal of Education and Learning (Edulearn), 9/4, 274-281. $\begin{array}{llll}\text { Retrieved } & 28 & \text { October, } & 2017\end{array}$ http://journal.uad.ac.id/index.php/EduLearn/article/view/2121/pdf_100.

Jaelani \& Retnawati, H. (2016). The challenges of junior high school mathematics teachers in implementing the problem-based learning for improving the higher-order thinking skills. The Online Journal of Counseling and Education, 5/3, 1-13. Retrieved 17 October, 2017 from http://www.tojce.com/frontend//articles/pdf/v5i3/1-13tojce-jailani-heriretnawatipdf.pdf.

Jonassen, D. H. (2014). Assessing problem-solving. Spector, J. M., Merril, J. M., Elen, J., \& Bishop, M. J. (Eds.), Handbook of research on education communication and technology, 269-288.

Kramarski, B., Mevarech, Z. R., \& Arami, M. (2002). The effects of metacognitive instruction on solving mathematical authentic tasks. Educational Studies in Mathematics, 49/2, 225-250. $\quad$ Retrieved $16 \quad$ October, 2017 from https://link.springer.com/article/10.1023/A:1016282811724.

Kramarski, B., \& Mevarech, Z. R. (2003). Enhancing mathematical reasoning in the classroom: the effects of cooperative learning and metacognitive training. American Educational Research Journal, 40/1, 281-310. Retrieved 16 October, 2017 from http://journals.sagepub.com/doi/pdf/10.3102/00028312040001281.

Letsekha, T., Wiebesiek-Pienaar, L. W., \& Meyiwa, T. (2014). Reflecting on the development of context-relevant teaching tools using local and indigenous knowledge. In J.G. Laborda, F. Ozdamli, \& M. Maasoglu (Eds.), Proceeding of $5^{\text {th }}$ World Conference on Educational Sciences -WCES. Rome, Italy (pp. 4577-4581). Barcelona, Spain: Elsevier.

Mevarech, Z., \& Fridkin, S. (2006). The effects of IMPROVE on mathematical knowledge, mathematical reasoning, and meta-cognition. Metacognition and Learning, 1/1, 85-97. Retrieved 16 October, 2017 from https://link.springer.com/article/10.1007/s11409-0066584-x.

Özsoy, G., \& Ataman, A. (2009). The effect of metacognitive strategy training on mathematical problem-solving achievement. International Electronic Journal of Elementary Education, 1/1, 67-82. Retrieved 3 February, 2017 from https://www.Researchgate.Net/Publication/277739337.

Park, J. Y., \& Muntrakune, T. (2013). A conceptual framework for the cultural integration of cooperative learning: a Thai primary education perspective. Journal of Mathematics, Science and Technology Education, 9/3, 247-258. Retrieved 16 October, 2017 from http://dx.doi.org/10.12973/eurasia.2013.933a.

Polya, G. (1973). How to solve it. Princeton, N. J.: Princeton University Press. 
Prediger, S. (2004). Intercultural perspectives on mathematics learning - developing a theoretical framework. International Journal of Science and Mathematics Education, 2/3, 377-406. Retrieved 16 October, 2017 from https://link.springer.com/article/10.1007/s10763004-2685-7.

Sarjoko (2003). Implikasi model IMPROVE dalam pembelajaran pangkat rasional dengan setting kooperatif di SMAN-2 Palangka Raya-Kalimantan Tengah. [Implication of IMPROVE model in rational exponent learning using cooperative setting in SMAN-2 Palangka Raya-Central Kalimantan]. Thesis. Malang-Indonesia: State University of Malang.

Sharif, A. \& Gisber, M. (2015). The impact of culture on design instructional and quality. International Journal of Instruction, 8/1, 143-156. Retrieved 16 October, 2017 from http://www.e-iji.net/dosyalar/iji_2015_1_11.pdf.

Tarzimah, T.,\& Meerah, T. S. M. (2010). Students' difficulties in Mathematics problemsolving: what do they Say? In R.A. Tarmizi\& A. F. M. Ayub (Eds.), Proceeding ofInternational Conference on Mathematics Education Research 2010. Malaysia (pp. 142151). Malaysia: Universiti Kebangsaan Malaysia. Retrieved 14 November, 2016 from http://www.sciencedirect.com/science/article/pii/S1877042810021257.

Taylor, B. V. (2009). How Ngaju Dayak Christian Women In The Three Rural Communities In Central Kalimantan Pass On Their Skills, And Values To The Next Generation? (Doctoral Dissertation). Retrieved 16 November, 2016 from https://www.Researchgate.Net/Publication/277739337.

Verner, I., Massarwe, K., \& Bshouty, D. (2013). Constructs of engagement emerging in an ethnomathematical-based teacher education course. The Journal of Mathematical Behavior, 32/3, 494-507. Retrieved 17 October, 2017 from http://linkinghub.elsevier.com/retrieve/pii/S0732312313000539.

Warren, E., Cooper, T. J., \& Baturo, A. (2004). Indigenous students and mathematics: teachers' perceptions of the role of teacher aides. The Australian Journal of Indigenous Education, 33/3), 37-46. Retrieved 22 November, 2016 from https://eprints.qut.edu.au/10223/1/10223.pdf.

Weldeana, H. N. (2015). Gender positions and high school students' attainment in local geometry. International Journal of Science and Mathematics Education, 13/6, 1331-1354. Retrieved 7 January, 2017 from https://link.springer.com/article/10.1007/s10763-014-9548-7.

Yanarita, Naiem, M., Budiadi, \& Sukarna. (2014). Development of the Dayak Ngaju community forest in the forest and peatland area, Central Kalimantan, Indonesia. IOSR Journal of Environmental Science, Toxicology and Food Technology, 8/3, 40-47. Retrieved 13 November, 2016 from https://www.Researchgate.Net/Publication/277739337.

Yuan, S. (2013). Incorporating Pólya's problem-solving method in remedial math. Journal of Humanistic Mathematics, 3/1, 96-107. Retrieved 15 November, 2016 from Retrieved 13 November 2016 from http://scholarship .claremont.edu/jhm/vol3/iss1/8.

Zedda, M., Bernardelli, S., \& Maran, D. A. (2017). Students' satisfaction with the group work method and its performance evaluation: a survey in an Italian University. International Journal of Instruction, 10/3, 1-14. Retrieved 16 October, 2017 from https://doi.org/10.12973/iji.2017.1031a. 